\title{
SOIL LOSS RISK AND HABITAT QUALITY IN STREAMS OF A MESO-SCALE RIVER BASIN
}

\author{
Alexandre Marco da Silva ${ }^{1 *}$; Lilian Casatti²; Clayton Alcarde Alvares ${ }^{3}$; Aline Maria Leite ${ }^{3}$; \\ Luiz Antonio Martinelli ${ }^{3}$; Steven F. Durrant ${ }^{1}$ \\ ${ }^{1}$ UNESP - Campus Experimental de Sorocaba - Av. Três de Março, 511 - 18087-180 - Sorocaba, SP - Brasil. \\ ${ }^{2}$ UNESP/IBILCE - Depto. de Zoologia - R. Cristóvão Colombo, 2265 - 15054-000 - São José do Rio Preto, SP - \\ Brasil. \\ ${ }^{3}$ USP/CENA - C.P. 96 - 13400-970 - Piracicaba, SP - Brasil. \\ *Corresponding author <amsilva@sorocaba.unesp.br>
}

\begin{abstract}
Soil loss expectation and possible relationships among soil erosion, riparian vegetation and water quality were studied in the São José dos Dourados River basin, State of São Paulo, Brazil. Through Geographic Information System (GIS) resources and technology, Soil Loss Expectation (SLE) data obtained using the Universal Soil Loss Equation (USLE) model were analyzed. For the whole catchment area and for the $30 \mathrm{~m}$ buffer strips of the streams of 22 randomly selected catchments, the predominant land use and habitat quality were studied. Owing mainly to the high soil erodibility, the river basin is highly susceptible to erosive processes. Habitat quality analyses revealed that the superficial water from the catchments is not chemically impacted but suffers physical damage. A high chemical purity is observed since there are no urban areas along the catchments. The water is physically poor because of high rates of sediment delivery and the almost nonexistence of riparian vegetation. Key words: erosion modeling, expectation of soil loss map, riparian vegetation, water quality
\end{abstract}

\section{RISCO DE PERDADE SOLO E QUALIDADE DO HABITAT NUMA BACIA HIDROGRÁFICA DE MESO-ESCALA}

\begin{abstract}
RESUMO: Expectativa de perda de solo e possíveis relações entre erosão, vegetação ripária e qualidade da água foram estudados na bacia do rio São José dos Dourados (SP). Através de recursos de geoprocessamento e da Equação Universal de Perda de Solos, os dados sobre expectativa de perda de solo foram levantados. Para a área de drenagem total e a faixa tampão dos corpos d'água de 22 subbacias aleatoriamente selecionadas, analisou-se a cobertura do solo predominante e qualidade do habitat. Devido principalmente à alta erodibilidade do solo, a área estudada é altamente suscetível ao processo erosivo. As análises de qualidade da água revelaram que as águas superficiais das subbacias estão quimicamente não impactadas, mas fisicamente degradadas. A alta pureza química devese, possivelmente, à ausência de áreas urbanizadas ao longo das sub-bacias e as alterações nas características físicas são, possivelmente, decorrentes das altas taxas de transferência de sedimento aos corpos d'água e à quase ausência de mata ciliar.

Palavras-chave: modelagem de erosão, expectativa de perda de solo, vegetação ripária, qualidade da água
\end{abstract}

\section{INTRODUCTION}

The land use of a catchment exerts an important impact on the erosive processes within a region (Lufafa et al., 2003; Costa et al., 2003) and on the health of rivers (Naiman \& Décamps, 1997). This relationship has been investigated worldwide (Silva \& Williams, 2001; Allan, 2004), and in Brazil some studies have been carried out to better understand such relations (Alvares \& Silva, 2005; Barrella \& Petrere, 2003; Casatti et al., 2006).

Owing to important and interesting components that are favorable to some human activities (Fischer et al., 2000; Allan, 2004) riparian vegetation has been constantly and directly affected by deforestation worldwide. Jobin et al. (2004) point out that in North America over $90 \%$ of riparian habitats have been lost over the last 200 years, mostly due to intensive agriculture, which has also contributed to the degradation of the originally forested landscape. In Brazil, especially in the São Paulo State, the level of degradation is similar (Kronka et al., 2002), and such degradation has occurred mainly over the last 100 years. Changes in riparian vegetation can influence channel morphology, rates of erosion and deposition, and by extension, the entire sediment budget of a reach (Allan, 2004). 
For this purpose, modern technology has provided effective analytical tools such as remote sensing and satellite imaging, GIS, and expert systems to facilitate studies of environmental impacts. Additionally, habitat and water quality are also evaluated using individual variables or combined metrics (Casatti et al., 2006). Thus, a wide variety of assessment methods is available to evaluate the response of stream conditions to a gradient in land use (Allan, 2004). Although these studies have become more common over the past 20 years, they leave many questions unanswered. For instance, there is still an ongoing dispute as to whether the land use of the entire catchment or that of the riparian zone is more important in influencing the water quality, all other factors remaining constant (Sliva \& Williams, 2001).

In this study we estimated the expectation of soil loss and also analyzed possible relationships that the erosive process has with the habitat quality in the river network of the São José dos Dourados river ba$\sin (\mathrm{SJD})$.

\section{MATERIAL AND METHODS}

\section{Study area}

The study area is a meso-scale river basin situated in the Northwest of São Paulo State (Southeastern Brazil), between latitudes $20^{\circ} 15^{\prime} 36^{\prime \prime}$ and $20^{\circ} 51^{\prime} 32^{\prime \prime}$ and longitudes $49^{\circ} 31^{\prime} 30^{\prime \prime}$ and $51^{\circ} 21^{\prime} 32^{\prime \prime}$ (Figure 1). It is a $6^{\text {th }}$ order basin (Strahler, 1957) and encompasses a drainage area of $5,158.9 \mathrm{~km}^{2}$. It comprises a delimited area for water resources and is located in the Serra Geral formation, with basalt and sedimentary rocks of the Caiuá and Bauru groups (IPT, 2000).

The climate is of the hot tropical type (Nimer, 1989), with maximum mean temperatures ranging from 31 to $32^{\circ} \mathrm{C}$, and minimum mean temperatures of $13^{\circ}$ to $14^{\circ} \mathrm{C}$. The average annual rainfall ranges from

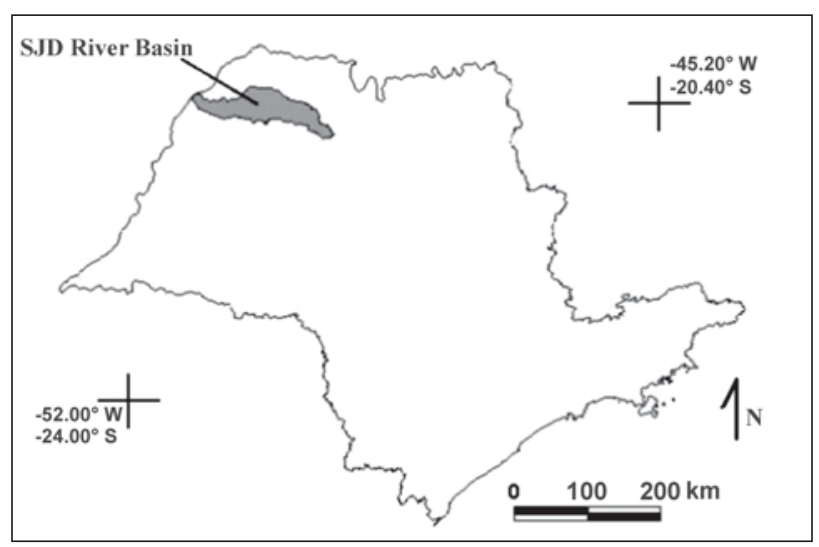

Figure 1 - Location of the study area within the São Paulo State.
1,300 to $1,800 \mathrm{~mm}$. The predominant original vegetation is "Semi Deciduous Seasonal Forest", but patches of Savanna ("Cerrado") also occur in the area.

The SJD river basin is an important agricultural region, presenting one of the highest livestock populations for milk and meat production in Brazil (named mix production - CATI, 2006). Thus, pasture is the main land-cover class that occurs in the region (Casatti et al., 2006). The soil and water resources have been severely degraded due to diverse causes: soil erosion (consequence of soil/soil-cover mismanagement), increasing urban populations and related water pollution problems, among others (Casatti et al., 2006; IPT, 2000).

\section{USLE application}

The soil loss expectation data were surveyed using the Universal Soil Loss Equation (Wischmeier \& Smith, 1978): A = R . K . L . S . C . P; where: A is the rate of soil loss $\left(t h^{-1} y^{-1}\right), R$ is a factor for annual rainfall erosivity (MJ mm ha- ${ }^{-1} \mathrm{y}^{-1}$ ), $\mathrm{K}$ is a factor for soil erodibility ( $\mathrm{t}$ ha h ha ${ }^{-1} \mathrm{MJ}^{-1} \mathrm{~mm}^{-1}$ ), L, S, C and $\mathrm{P}$ are dimensionless factors for slope length, slope steepness, cover management, and supporting practices, respectively. The information concerning to the six parameters of the USLE were computed using GIS technology (Idrisi 3.2 (Eastman, 2001)), as explained below.

$R$ factor - this layer was elaborated using the database and the digital map of the rainfall erosivity, extracted from the database elaborated and cited by Silva (2004). K factor - this one was generated by using the São Paulo State pedological map $(1: 500,000)$ and assigned values according to soil class as studied by Silva \& Alvares (2005). LS factor - a 30-meter resolution Digital Elevation Model (DEM) of the study area was used. By using the DEM and the USLE-2D freeware (Desmet \& Govers, 1996), the LS factor was generated, where the value of each cell corresponds to the LS factor. $C$ and $P$ factor - were generated (C and $\mathrm{P}$ jointly) using a digital land cover map, originally divided into ten land cover categories. This map was elaborated using a Landsat 5 (TM) image dated from July - 1996 and the supervised classification method (Lillesand \& Kiefer, 2000). The C and P values were assigned according to the land cover category obtained from Bertoni \& Lombardi Neto (1990); Mitchell \& Bubenzer (1980) and Silva (1999).

Once all existing information about each USLE factors and their respective layers was gathered, the soil loss expectation was calculated by the multiplication of the layers (Silva et al., 2003). The results were reclassified into five interpretation classes (Silva et al., 2003). 


\section{Riparian buffer zone determination}

Following Narumalani et al. (1997), the map containing the buffer zone of the river network of the study area was elaborated using the land cover and digital river network map. Subsequently, the dimension of the buffer zone (30 meters) was decided according to the values determined by the Brazilian Forest Code (Brasil, 1965). Hence, the buffer zones were extracted using the river network, and the "Buffer" routine of the Idrisi 3.2 software (Eastman, 2001). The maps containing the buffer zones and the land cover were overlayed ("Overlay" routine of the Idrisi, with the multiplication option), to generate a new map containing the land cover for the buffer zones only. Finally, the areas of each land cover class were calculated (“Area” routine of the Idrisi).

\section{Water and habitat quality analyses}

The water quality was determined for twenty two randomly chosen sampling points (Figure 2), sixteen located in first-order rivers, classified in accordance to the Strahler system of hydrographic hierarchy (Strahler, 1957), three points in second-order rivers and three in third-order rivers. To minimize the influence of the seasonal variability, field work was carried out during the beginning of the dry season (March to June, 2003). A $75 \mathrm{~m}$ stretch was chosen at each side of the stream with the aim of including all available macro-habitats (Casatti et al., 2006).

Water quality assessment included the development of physical and chemical water indexes (PCWI) and the physical habitat index (HI). For the composition of the PCWI at each sampling point the parameters dissolved oxygen, conductivity, $\mathrm{pH}$, turbidity (all measured “in situ” through digital meter Horiba ${ }^{\circledR}$, model U-10), orthophosphate, nitrate, and ammonia (all analyzed in a specialized laboratory) were measured. In addition, water odors were recorded and water surface oils were also visually documented as indicators of possible human disturbance of a stream reach (Barbour et al., 1999). All parameters were compared against conditions observed in the totally protected water courses in the Morro do Diabo State Park (Silva, 2005), where the Atlantic Forest covers the entire watersheds. A metric raw score was developed based on the deviation from the reference condition and the average final score for each site was separated into four categories (good, fair, poor, and very poor). The complete procedures of sampling can be found in Casatti et al. (2006).

Following Roth et al. (1996), nine metrics were used to compose the Habitat Index (HI), which are: substrate stability, velocity and depth variability, flow stability, bottom deposition, combinations of poolriffle-run, channel alteration, streamside cover, bank vegetative stability, and bank stability. Complete and detailed explanation of the PCWI and $\mathrm{HI}$ is available in Casatti et al. (2006).

All the sampling points were geo-referenced and plotted over the Digital Elevation Model of the study area using the Idrisi program. The respective catchment areas of each sampling point were on-screen and manually digitalized. The layer of drainage area of each of the sampling point was intersected with the SLE, land-cover and buffer maps. Using these maps, the catchment area, the percentage of occurrence of each class of the SLE map, of each land cover category (total catchment area) and of the predominant land cover category - specifically for the $30 \mathrm{~m}$ ripar-

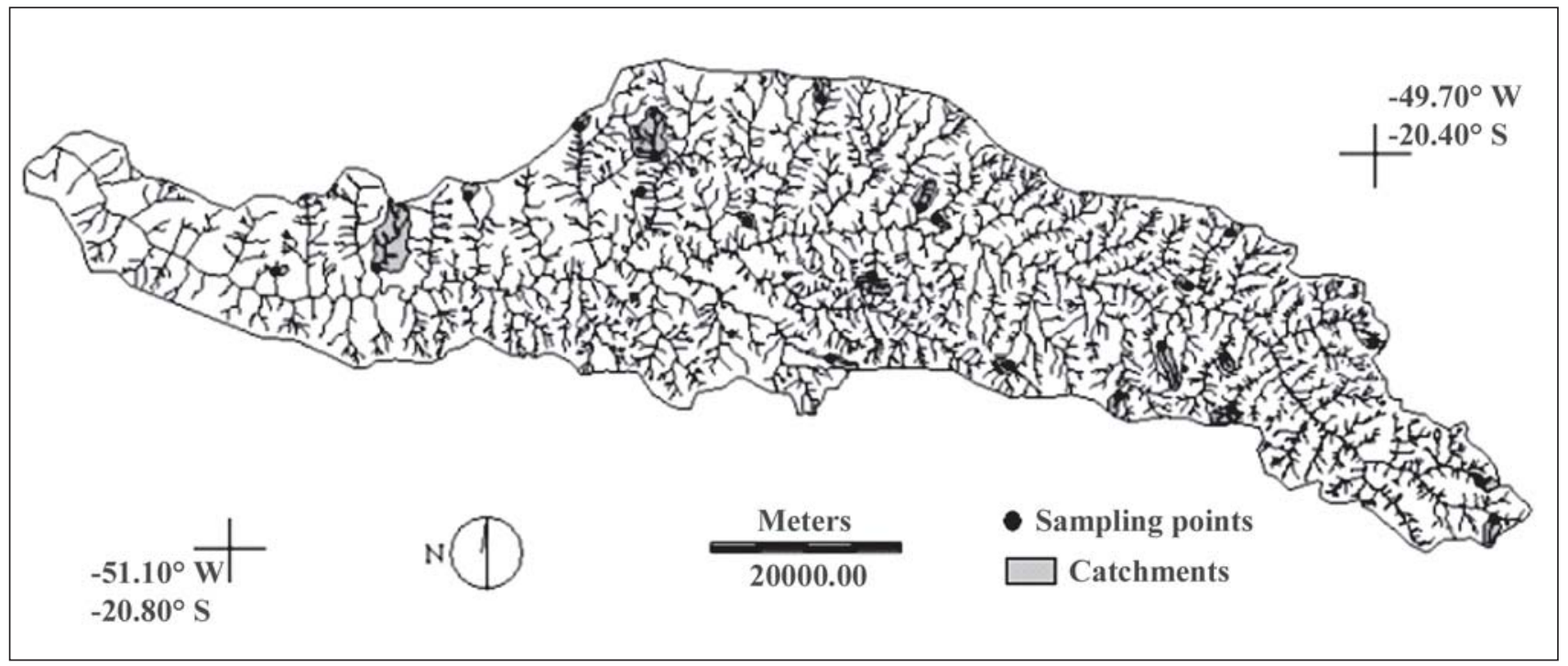

Figure 2 - Water quality sampling points and their respective catchments. 
ian zone (including the percentage of remnant riparian vegetation that occurs along the $30 \mathrm{~m}$ buffer strip) were calculated.

\section{RESULTS AND DISCUSSION}

\section{USLE application}

Annual erosivity of the studied area increased from east to west along the basin, ranging from 5,842 to 6,742 MJ mm ha ${ }^{-1} \mathrm{~h}^{-1} \mathrm{yr}^{-1}$, being considered of "medium-high" erosivity. The soil map and erodibility values for the region show that the soils of the river basin are highly erodible in approximately 94\% of the area. The soil class "Acrisol” occurs over $93.1 \%$ of the whole area and this class has the greatest erodibility, classified as "very high erodibility" mainly due the abrupt textural change and the high sand percentage (Oliveira et al., 1999; Silva \& Alvares, 2005).

The LS factor map was reclassified into six classes, according to LS values: " $<1$ " (occurring in $21.4 \%$ of the study area), “=1" $(0 \%)$. The classes " 3 ", " 4 ", " 5 ", and " 6 ", wich correspond, respectively, to intervals of "1.1-10.0”, "10.1-50.0", "50.1-100.0” and "> $>100.1$ ", occurred in $0.4 \%, 30.2 \%, 35.3 \%$ and $12.6 \%$, respectively. The LS factor closely reflected the overall topographic pattern of the region (predominance of flat to slowly undulating relief).

The land cover map of the basin (Figure 3) indicates pasture as the predominant land-cover class, occurring in $78.1 \%$. For this land-cover class the values 0.1607 and 0.7000 were attributed to $\mathrm{C}$ and $\mathrm{P}$ USLE factors, respectively. The remnant vegetation class occurs in $6.9 \%$ of the study area and the $\mathrm{C}$ and $\mathrm{P}$ values most appropriate for this class are 0.0024 and 1.000, respectively, (Bertoni \& Lombardi Neto, 1990; Mitchell \& Bubenzer, 1980; Silva, 1999).
The category "urban places" occurs in $0.6 \%$ of the river basin. The $\mathrm{C}$ factor was 0.1242 (Silva, 1999). Normally the value $P=1$ is attributed to this land cover category (Silva et al., 2003). In some cases, however, there are some activities developed within the urban area that can reduce erosion and land degradation. Consequently, considering this possibility, the $\mathrm{P}$ value adopted for "urban places" was 0.95. Reforestation is a land-cover category occurring in a very small percentage within the study area $(0.02 \%)$. The $C$ value was 0.0470 and the $P$ value was 1.000 . The attribution of $\mathrm{P}=1$ is because in Brazil usually no soil conservation practices are used in reforestation activities (Kronka et al., 2002). Thus, the combined C.P value is 0.047 .

The class "perennial cultures" occurs in $3.2 \%$ of the area, and is composed mainly of orange orchards and rubber tree plantations, although a few coffee plantations also occur. The values attributed were: $\mathrm{C}=0.2190$ and $\mathrm{P}=0.40$ (combined C.P $=$ 0.088 ). The class "annual crops" occurs in $0.20 \%$ of the study area and is represented by the corn and soybean fields. For this class the $\mathrm{C}$ and $\mathrm{P}$ values were, respectively, 0.1720 and 0.5000 (C.P $=0.086$ ) (Bertoni \& Lombardi Neto, 1990; Mitchell \& Bubenzer, 1980; Silva, 1999).

"Sugar cane" and "bare soil", two closely related land covers, occur in $2.1 \%$ and $6.9 \%$, respectively, of the SJD river basin. For sugar cane the attributed $\mathrm{C}$ and $\mathrm{P}$ values were, respectively, 0.1743 and 0.7000, while for bare soil the attributed values were, respectively, 1.000 (soil totally uncovered) and 0.70 (Mitchell \& Bubenzer, 1980). The combined C and P values were 0.122 and 0.700 , respectively, for sugar cane and bare soil. The class "water bodies" occurs in $1.82 \%$ of the area and has negligible significance

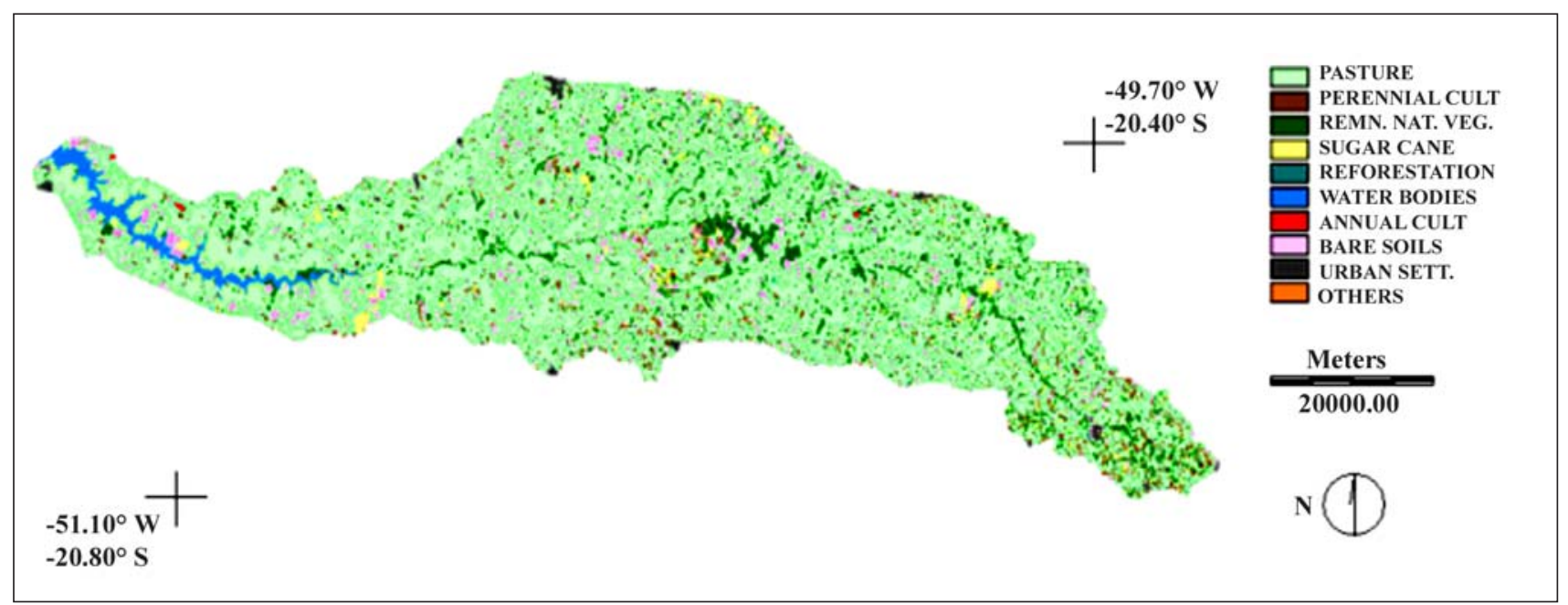

Figure 3 - Land cover map for SJD river basin. 
for soil loss, while the class "others" - that occurs in $0.2 \%$, was attributed by convention, the values 0.14 and 1.00, for $\mathrm{C}$ and $\mathrm{P}$ factors, respectively (Silva et al., 2003).

The result of the combination of the USLE factors revealed that there is a predominance of the class that indicates "very high" soil loss expectation (that means a soil loss expectation higher than $200 \mathrm{t} \mathrm{ha}^{-1}$ year $\left.^{-1}\right)$. This class occurs in $73.4 \%$ of the area. The class "null" $\left(0-10 \mathrm{t} \mathrm{ha}^{-1}\right.$ year $\left.^{-1}\right)$ is the second predominant class and occurs in $15.3 \%$, followed by class "medium" (15 - $50 \mathrm{t} \mathrm{ha}^{-1}$ year $\left.^{-1}\right)$ with 7.3\%, "medium to high" (50 - 120 t ha $^{-1}$ year $^{-1}$ ) with 2.9\%, "high” (120 - 200 t ha $^{-1}$ year $^{-1}$ ) with $0.8 \%$ and "moderate" (10 $15 \mathrm{t} \mathrm{ha}^{-1}$ year $^{-1}$ ) with $0.3 \%$. Through the routine "regress" of the Idrisi, it was possible to verify that the USLE factor that presented the closest relation with SLE was the CP $\left(r^{2}=0.491\right)$.

\section{Water and habitat quality analyzes}

Table 1 summarizes the percentage occurrence of each soil loss expectation, the percentage of remnant riparian vegetation for a $30 \mathrm{~m}$ buffer strip, the number of headwaters, the main land-use in the catchments and in the respective $30 \mathrm{~m}$ buffer strip, and the classification of physical, chemical and habitat quality indexes.

As occurred in the whole river basin, pasture was the predominant land cover class for the 22 investigated catchments, with occurrences higher than $75 \%$. Similarly, pasture was the main land cover class that occurred for the $30 \mathrm{~m}$ buffer for most catchments, the only exception being catchment number eighteen, where for the buffer zone the predominant land cover class was remnant natural vegetation.

The results of physico-chemical and habitat quality analyses indicate that the streams are only slightly affected chemically, because eighteen catchments presented a physico-chemical condition classified as "good" and four classified as "fair". On the other hand, the habitat characteristics are strongly affected, because one catchment had a physical quality classified as "very poor", sixteen were considered "poor", five "fair" and not a single one was considered as "good". The percentage of riparian remnant forest along the $30 \mathrm{~m}$ buffer strip varied from 0 to $50.8 \%$ and eight of them did not present any riparian vegetation cover.

The soil loss expectation class " $>200 \mathrm{t} \mathrm{ha}^{-1} \mathrm{y}^{-1 \text { " }}$ presented predominant occurrence in all twenty-two catchments, the occurrence varying from 59.8 to $90.4 \%$. The hierarchical order of the stream did not impede the degradation of the habitat quality and the level of degradation can be ratified by the soil expectation loss, which for all watersheds was predominantly “> 200”.
Regarding the erosive process, the western region of the state presents elevated susceptibility to erosion because of the high erodibility of both the soil and the geological basement (IPT, 1997), which results in sandy and highly detachable soils. Other river basins located in such regions (Aguapeí, Peixe, for instance) also present high susceptibility to erosion for the same reason (IPT, 1997).

The resulting database obtained in this study concerning soil loss expectation is in agreement with the erosion map published by IPT (1997) for the entire São Paulo State, based on geological, pedological and geomorphological maps. The high occurrence of areas showing high expectation of soil loss was also verified by Cerri et al. (2001) for Piracicaba River Basin and, according to these authors, the main driving forces were the kind of land cover and the absence of adequate soil tillage practices.

Because the studied region may be highly susceptible to erosive processes, the use of conservation practices is crucial, but the scenario is completely different. Through field trips it was verified that the use of soil conservation practices is rare, relatively recent, and in some regions the cattle density is high, leading to overgrazing. Pasture, the main land-cover class reported in this study, is a long term and significant part of SJD land use and is a critical component of rural landscape in São Paulo State. The main function of pasture is as a primary support system for livestock. It can affect conservation and environmental planning in several ways, including soil carbon storage, soil quality, and water quality. Depending on the way livestock and pasture are managed, the effect of livestock on such parameters is highly significant (Al-Kaisi \& Hanna, 2004).

The class "urban settlement" did not occur in any of the 22 catchments. This is, probably, the primary and main reason that explains the good chemical quality of the water observed for almost all catchments. Sliva \& Williams (2001) mention urbanization as the main factor that influences the chemical quality of streams in Ontario (Canada), a result also supported by Daniel et al. (2002) for the Piracicaba River Basin (Brazil).

The second possible cause that explains the good chemical condition of the stream water is the chemical composition of the soil types of the catchment area. Acrisol is the predominant soil unit (Oliveira et al., 1999) and the Acrisol occurring in São Paulo State is mostly sandy, with clays of low activity (Bertoni \& Lombardi Neto, 1990). This indicates that the amount of chemical components removed from the soil and delivered to the drainage channels is relatively low. 
Table 1 - Relationships among the physical and chemical characteristics of the water; percentage of 30-m riparian vegetation and soil loss expectation for five sub-watersheds of the SJD river basin.

\begin{tabular}{|c|c|c|c|c|c|c|c|c|c|c|c|c|c|c|}
\hline \multicolumn{3}{|c|}{ Sample point } & \multicolumn{6}{|c|}{ Occurrence of each SLE class } & \multirow{2}{*}{$\begin{array}{c}\% 30 \mathrm{~m} \\
\text { R.R.V. }\end{array}$} & \multirow{2}{*}{$\begin{array}{c}\text { N. } \\
\text { Headw. }\end{array}$} & \multicolumn{2}{|c|}{ Main land use } & \multirow{2}{*}{$\begin{array}{l}\text { Chem. } \\
\text { Info. }\end{array}$} & \multirow{2}{*}{$\begin{array}{l}\text { Phys } \\
\text { Info. }\end{array}$} \\
\hline n. & H. O. & D.Area & $<10$ & $10-15$ & $15-50$ & $50-120$ & $120-200$ & $>200$ & & & Gen. & Rip. Z. & & \\
\hline 1 & $1^{\text {st }}$ & 159.3 & 21.2 & 0.0 & 8.4 & 0.0 & 0.3 & 70.1 & 0.0 & 1 & $\begin{array}{c}\text { Pasture } \\
(97 \%)\end{array}$ & $\begin{array}{l}\text { Pasture } \\
(100 \%)\end{array}$ & Good & Poor \\
\hline 2 & $2^{\text {nd }}$ & 3352.1 & 15.3 & 0.3 & 8.9 & 1.1 & 0.3 & 74.2 & 4.8 & 7 & $\begin{array}{c}\text { Pasture } \\
(84 \%)\end{array}$ & $\begin{array}{c}\text { Pasture } \\
(90 \%)\end{array}$ & Fair & Fair \\
\hline 3 & $1^{\text {st }}$ & 301.3 & 10.6 & 0.2 & 8.9 & 0.7 & 0.8 & 78.8 & 0.0 & 1 & $\begin{array}{c}\text { Pasture } \\
(85 \%)\end{array}$ & $\begin{array}{c}\text { Pasture } \\
(78 \%)\end{array}$ & Good & Poor \\
\hline 4 & $1^{\text {st }}$ & 282.1 & 9.2 & 0.0 & 9.3 & 0.8 & 0.2 & 80.4 & 0.0 & 1 & $\begin{array}{l}\text { Pasture } \\
(88.3 \%)\end{array}$ & $\begin{array}{l}\text { Pasture } \\
(100 \%)\end{array}$ & Good & V. P. \\
\hline 5 & $1^{\text {st }}$ & 80.0 & 8.9 & 0.0 & 6.7 & 0.4 & 0.0 & 84.1 & 0.0 & 1 & $\begin{array}{l}\text { Pasture } \\
\text { (78.9\%) }\end{array}$ & $\begin{array}{l}\text { Pasture } \\
(100 \%)\end{array}$ & Good & Poor \\
\hline 6 & $3^{\text {rd }}$ & 2394.7 & 10.8 & 0.2 & 7.3 & 1.8 & 0.6 & 79.3 & 7.3 & 14 & $\begin{array}{l}\text { Pasture } \\
(81.9 \%)\end{array}$ & $\begin{array}{l}\text { Pasture } \\
\text { (73.0\%) }\end{array}$ & Good & Poor \\
\hline 7 & $1^{\text {st }}$ & 179.6 & 10.6 & 0.2 & 5.9 & 0.6 & 0.2 & 82.5 & 0.0 & 1 & $\begin{array}{l}\text { Pasture } \\
(82.6 \%)\end{array}$ & $\begin{array}{l}\text { Pasture } \\
\text { (98.1\%) }\end{array}$ & Good & Poor \\
\hline 8 & $1^{\text {st }}$ & 317.3 & 8.3 & 0.3 & 9.5 & 1.8 & 0.9 & 79.2 & 3.3 & 1 & $\begin{array}{l}\text { Pasture } \\
(79.3 \%)\end{array}$ & $\begin{array}{l}\text { Pasture } \\
(61.7 \%)\end{array}$ & Good & Poor \\
\hline 9 & $1^{\text {st }}$ & 413.1 & 28.7 & 0.2 & 6.5 & 0.8 & 0.2 & 63.5 & 18.2 & 1 & $\begin{array}{l}\text { Pasture } \\
(81.2 \%)\end{array}$ & $\begin{array}{l}\text { Pasture } \\
(61.4 \%)\end{array}$ & Good & Poor \\
\hline 10 & $3^{\text {rd }}$ & 695.1 & 9.3 & 0.2 & 8.1 & 1.2 & 0.6 & 80.5 & 6.9 & 7 & $\begin{array}{l}\text { Pasture } \\
\text { (78.9\%) }\end{array}$ & $\begin{array}{c}\text { Pasture } \\
\text { (82.5) }\end{array}$ & Good & Fair \\
\hline 11 & $2^{\text {nd }}$ & 696.8 & 11.5 & 0.2 & 6.8 & 0.3 & 0.5 & 80.7 & 0.6 & 3 & $\begin{array}{l}\text { Pasture } \\
\text { (89.1\%) }\end{array}$ & $\begin{array}{l}\text { Pasture } \\
(94.8 \%)\end{array}$ & Good & Fair \\
\hline 12 & $1^{\text {st }}$ & 118.6 & 27.7 & 0.3 & 7.3 & 0.1 & 0.0 & 64.6 & 0.0 & 1 & $\begin{array}{l}\text { Pasture } \\
\text { (75.3\%) }\end{array}$ & $\begin{array}{l}\text { Pasture } \\
\text { (54.4\%) }\end{array}$ & Fair & Poor \\
\hline 13 & $1^{\text {st }}$ & 202.7 & 15.6 & 0.2 & 11.5 & 4.6 & 1.2 & 66.9 & 28.3 & 1 & $\begin{array}{l}\text { Pasture } \\
(75 \%)\end{array}$ & $\begin{array}{l}\text { Pasture } \\
\text { (66.2\%) }\end{array}$ & Good & Poor \\
\hline 14 & $1^{\text {st }}$ & 290.6 & 7.4 & 0.0 & 5.8 & 1.1 & 0.8 & 84.9 & 3.2 & 1 & $\begin{array}{l}\text { Pasture } \\
(87.2 \%)\end{array}$ & $\begin{array}{l}\text { Pasture } \\
\text { (94.9\%) }\end{array}$ & Good & Poor \\
\hline 15 & $1^{\text {st }}$ & 799.6 & 22 & 0.3 & 4.1 & 3.7 & 0.6 & 69.4 & 8.4 & 1 & $\begin{array}{l}\text { Pasture } \\
(75.3 \%)\end{array}$ & $\begin{array}{l}\text { Pasture } \\
\text { (86.9\%) }\end{array}$ & Good & Poor \\
\hline 16 & $1^{\text {st }}$ & 245.1 & 22.1 & 0.0 & 6.0 & 0.8 & 0.8 & 70.4 & 0.0 & 1 & $\begin{array}{l}\text { Pasture } \\
(86.5 \%)\end{array}$ & $\begin{array}{l}\text { Pasture } \\
\text { (78.3\%) }\end{array}$ & Good & Poor \\
\hline 17 & $1^{\mathrm{st}}$ & 190.3 & 3.5 & 0.2 & 6.8 & 3.9 & 1.2 & 84.3 & 22.4 & 1 & $\begin{array}{l}\text { Pasture } \\
(76.4 \%)\end{array}$ & $\begin{array}{l}\text { Pasture } \\
\text { (77.6\%) }\end{array}$ & Fair & Poor \\
\hline 18 & $1^{\text {st }}$ & 244.5 & 18.5 & 0.3 & 5.2 & 2.6 & 1.6 & 71.8 & 50.8 & 1 & $\begin{array}{l}\text { Pasture } \\
(75 \%)\end{array}$ & $\begin{array}{l}\text { Rip. Veg. } \\
(50.8 \%)\end{array}$ & Good & Fair \\
\hline 19 & $3^{\text {rd }}$ & 637.9 & 28.3 & 0.3 & 8.7 & 2.5 & 0.5 & 59.8 & 12.4 & 6 & $\begin{array}{c}\text { Pasture } \\
(87 \%)\end{array}$ & $\begin{array}{l}\text { Pasture } \\
(84.5 \%)\end{array}$ & Good & Poor \\
\hline 20 & $1^{\mathrm{st}}$ & 78.8 & 3.8 & 0.0 & 5.1 & 0.2 & 0.4 & 90.4 & 34.8 & 1 & $\begin{array}{l}\text { Pasture } \\
(89.4 \%)\end{array}$ & $\begin{array}{l}\text { Pasture } \\
\text { (60.9\%) }\end{array}$ & Fair & Poor \\
\hline 21 & $2^{\text {nd }}$ & 285.6 & 9.8 & 0.0 & 8.2 & 2.2 & 0.6 & 79.1 & 3.6 & 2 & $\begin{array}{l}\text { Pasture } \\
(82.2 \%)\end{array}$ & $\begin{array}{l}\text { Pasture } \\
(90.5 \%)\end{array}$ & Good & Poor \\
\hline 22 & $1^{\mathrm{st}}$ & 596.7 & 14.8 & 0.0 & 6.9 & 2.2 & 0.0 & 76.1 & 0.0 & 1 & $\begin{array}{c}\text { Pasture } \\
(80 \%)\end{array}$ & $\begin{array}{l}\text { Pasture } \\
\text { (72.8\%) }\end{array}$ & Good & Fair \\
\hline
\end{tabular}

Abbreviations: n. - number of the sample point; H. O. - hierarchical order; D. Area - drainage area (hectares); R.R.V. - remnant riparian vegetation; N. Headw. - number of headwaters; Gen - all drainage area. Rip. Z. - 30 m riparian zone; Chem. Info / Phys. Info - chemical and physical information, respectively, V.P. - very poor. 
The third possible reason is that the farmers do not use fertilizers in pasture management (the main species used for pasture seems to be Brachiaria decumbens Stapf). Thus, when runoff occurs, there is no fertilizer to be transported. On the other hand, as this species is tolerant to soils of low fertility and is highly adapted to Brazilian climatic conditions, it is widely used (Mattos, 2001). As cattle are normally mismanaged and the pasture is typically overgrazed, the soil surface becomes poorly covered and highly susceptible to erosion (Sparovek, 1996).

The association of livestock with pasture management, and the need for livestock to have access to water, also intensifies the problems associated to soil stability and water quality (Al-Kaisi \& Hanna, 2004). The deterioration of pasture cover due to intensive grazing can be a very significant source of pollution from both sediment and animal waste. To improve the water quality of the SJD river basin, the producers that work with livestock in pasture should find ways to keep animals out of streams and find alternative water sources. Rotational grazing might be a good option for managing the quantity and quality of vegetation so as to improve water quality, since this kind of management system allows soil and vegetation time to recover from grazing and restore good soil conditions (Al-Kaisi \& Hanna, 2004).

The majority of the stream reaches (77.2\%) present poor or very poor physical habitat conditions for supporting aquatic wildlife communities (especially fishes, according to Casatti et al., 2006). Such authors observed, through field visits, that many small first-order streams listed in the official hydrographic map of the SJD river basin (which is from the 1970s) do not exist anymore, being dry and completely silted. This current and hazardous situation of high level degradation of the water (physical parameters) of the in-stream habitat of the SJD river basin is partially due to the high level of degradation of the riparian vegetation existing in the catchments (Sliva \& Williams, 2001; Allan, 2004).

The study area is in a worse condition than that showed in IPT (1997 and 2000). Therefore, it is suggested that extremely urgent and planned actions are adapted, perhaps beginning the restoring actions of the catchments with $0 \%$ riparian vegetation (Table 1 ). These areas should be the first to receive action and resources owing to the present expectation of soil loss. The divulgation of these data to city managers and regional populations is also extremely important and urgent to show the seriousness of the situation, to stimulate the perception of the need for environmental conservation / repair, and also to facilitate a joint and cohesive action to improve the environmental quality of the São José dos Dourados River Basin.

\section{CONCLUSIONS}

The predominant land cover (pasture) and soil mismanagement have intensified erosion within the study area. The results revealed the high level of environmental degradation that the SJD river basin is suffering, with $77.2 \%$ of the catchments having water of poor or very poor physical characteristics for the sustenance of aquatic wildlife. Actions for the restoration of the riparian vegetation (or, at least, a part of it) are extremely important and urgent to conserve and recuperate water resources and wildlife (terrestrial and aquatic) of this river ba$\sin$.

\section{ACKNOWLEDGEMENTS}

To Fundação de Amparo à Pesquisa do Estado de São Paulo (FAPESP) and Fundunesp, for financial support and scholarships.

\section{REFERENCES}

AL-KAISI, M.; HANNA, M. Integrated crop management. The role of pasture in conservation management. Ames: Iowa State University, 2004. Available at: http://www.ipm.iastate.edu/ipm/ icm/2004/8-16-2004/pasture.html.

ALLAN, J.D. Landscapes and Riverscapes: the influence of land use on stream ecosystems. Annual Review of Ecology, Evolution and Systematics, v.35, p.257-284, 2004.

ALVARES, C.A.; SILVA, A.M. Cenários de uso da terra e a expectativa de perda de solo para a Microbacia Hidrográfica do Ribeirão da Onça (Brotas / SP). Revista de Estudos Ambientais, v.7, p.77-90, 2005.

BARBOUR, M.T.; GERRITSEN, J.; SNYDER, B.D.; STRIBLING, J.B. Rapid bioassessment protocols for use in streams and wadeable rivers: periphyton, benthic macroinvertebrates and fish. 2.ed. Washington, DC: Environmental Protection Agency, 1999. 339p.

BARRELLA, W.; PETRERE, M. Fish community alterations due to pollution and damming in Tietê and Paranapanema Rivers Brazil. River Research and Applications, v.19, p.59-76, 2003.

BERTONI, J.; LOMBARDI NETO, F. Conservação do solo. São Paulo: Ícone, 1990. 335p.

BRASIL. Conselho Florestal Federal. Código florestal brasileiro. Brasília, 1965. Available at: www.ipef.br/legislacao.

CASATTI, L.; LANGEANI, F.; SILVA, A.M.; CASTRO, R.M.C. Stream fishes and environmental variables in a pasture dominated landscape, southeastern Brazil. Brazilian Journal of Biology, v.66, p.681-696, 2006.

COORDENADORIA DE ASSISTÊNCIA TÉCNICA INTEGRAL CATI. Mapas agrícolas. Campinas: CATI. Available online: www.cati.sp.gov.br. 2006.

CERRI, C.E.P.; DEMATTE, J.A.M.; BALLESTER, M.V.R.; MARTINELLI, L.A.; VICTORIA, R.L.; ROOSE, E. GIS erosion risk assessment of the Piracicaba river basin, Southeast Brazil. Mapping Sciences and Remote Sensing, v.38, p.157-171, 2001.

COSTA, M.H.; BOTTA, A.; CARDILLE, J.A. Effects of largescale changes in land cover on the discharge of the Tocantins River, Southeastern Amazonia. Journal of Hydrology, v.283, p.206-217, 2003. 
DANIEL, M.H.B.; MONTEBELO, A.A.; BERNARDES, M.C.; OMETTO, J.P.H.B.; CAMARGO P.B.; KRUSCHE, A.V.; BALLESTER, M.V.; VICTÓRIA, R.L.; MARTINELLI, L.A. Effects on urban sewage on dissolved oxygen, dissolved inorganic and organic carbon, and electrical conductivity on small streams along a gradient of urbanization in the Piracicaba river basin. Water, Air, and Soil Pollution, v.136, p.189-206, 2002.

DESMET, P.J.J.; GOVERS, G.A GIS procedure for automatically calculating LS factor on topographically complex landscape units. Journal of Soil and Water Conservation, v.51, p.427433, 1996

EASTMAN, J.R. Idrisi 3.2 - Release 2: Tutorial. Worcester, Massachusetts: Clark University, 2001.

FISCHER, R.A.; CHESTER, O.M.; FISCHENICH, J.C. Improving riparian buffer strips and corridors for water quality and wildlife. In: INTERNATIONAL CONFERENCE ON RIPARIAN ECOLOGY AND MANAGEMENT IN MULTI-LAND USE WATERSHEDS, Portland, 2000. Middleburg: AWRA, 2000. 7p. Available at: http://www.swf.usace.army.mil/pubdata/environ/ regulatory/other/links/stream/improvingriparianbufferstrips.pdf.

INSTITUTO DE PESQUISAS TECNOLÓGICAS DO ESTADO DE SÃO PAULO - IPT. Mapa de erosão do Estado de São Paulo. São Paulo, 1997. Scale: 1:3,000,000.

INSTITUTO DE PESQUISAS TECNOLÓGICAS DO ESTADO DE SÃO PAULO - IPT. Diagnóstico da situação atual dos recursos hídricos e estabelecimento de diretrizes técnicas para a elaboração do Plano da Bacia Hidrográfica do São José dos Dourados. São Paulo: Comitê da Bacia Hidrográfica do São José dos Dourados; Fundo Estadual de Recursos Hídricos, 2000 .

JOBIN, B.; BELANGER, L.; BOUTIN, C.; MAISONNEUVE, C. Conservation value of agricultural riparian strips in the Boyer River watershed, Québec (Canada). Agriculture, Ecosystems \& Environment, v.103, p.413-423, 2004.

KRONKA, F.J.N.; NALON, M.A.; MATSUKUMA, C.K.; PAVÃO, M.; KANASHIRO, M.M.; YWANE, M.S.S.; LIMA, L.M.P.R.; GUILLAUMON, J.R.; BAITELLO, J.B.; MONTEIRO, C.H.B. Inventário florestal das áreas reflorestadas do Estado de São Paulo. São Paulo: Secretaria do Meio Ambiente; Instituto Florestal, 2002. 183p.

LILLESAND, T.M.; KIEFER, R.W. Remote sensing and image interpretation. 4.ed. New York: John Willey \& Sons, 2000. $724 \mathrm{p}$

LUFAFA, A.; TENYWA, M.M.; ISABIRYE, M.; MAJALIWA, M.J.G.; WOOMER, P.L. Prediction of soil erosion in a Lake Victoria basin catchment using a GIS-based Universal Soil Loss model. Agricultural Systems, v.76, p.883-894, 2003.

MATTOS, W.T. Avaliação de pastagem de capim-braquária em degradação e sua recuperação com suprimento de nitrogênio e enxofre. Piracicaba: USP/ESALQ, 2001. 97p. (Tese Doutorado).
MITCHELL, J.K.; BUBENZER, G.D. Soil loss estimation. In: KIRKBY, M.J.; MORGAN, R.P.C. (Ed.). Soil erosion. Chichester: John Wiley \& Sons, 1980. p.17-62.

NAIMAN, R.J.; DÉCAMPS, H. The ecology of interfaces: Riparian Zones. Annual Review of Ecology and Systematics, v.28, p.621-658, 1997.

NARUMALANI, S.; YINGCHUN, Z.; JENSEN, J.R. Application of remote sensing and geographic information systems to the delineation and analysis of riparian buffer zones. Aquatic Botany, v.58, p.393-409, 1997.

NIMER, E. Climatologia do Brasil. Rio de Janeiro: Secretaria de Planejamento e Coordenação da Presidência da República; IBGE, 1989. 421p.

OLIVEIRA, J.B.; CAMARGO, M.N.; ROSSI, M.; CALDERANO FILHO, B. Mapa pedológico do Estado de São Paulo. Legenda expandida. Campinas: Instituto Agronômico, 1999. 112p. (Boletim Científico, 45).

ROTH, N.E.; ALLAN, J.D.; ERICKSON, D.L. Landscape influences on stream biotic integrity assessed at multiple spatial scales. Landscape Ecology, v.11, p.141-156, 1996.

SILVA, A.M. Aplicações de técnicas de geoprocessamento no estudo das relações entre os processos erosivos e sedimentológicos de bacia hidrográfica. São Carlos: EESC/USP, 1999. 249p. (Tese Doutorado).

SILVA, A.M. Rainfall erosivity map for Brazil. Catena, v.57, p.251-259, 2004.

SILVA, A.M.; ALVARES, C.A. Erodibilidade dos solos paulistas: levantamento de informações e estruturação de um banco de dados. Geociências, v.24, p.33-42, 2005.

SILVA, A.M.; SCHULZ, H.E.; CAMARGO, P.B. Erosão e hidrossedimentologia em bacias hidrográficas. São Carlos: Editora Rima, 2003. 110p.

SILVA, D.M.L. Dinâmica de nitrogênio em microbacias no Estado de São Paulo. Piracicaba: ESALQ/USP, 2005. 106p. (Tese de Doutorado).

SLIVA, L.; WILLIAMS, D.D. Buffer zone versus whole catchment approaches to studying land use impact on river water quality. Water Research, v.35, p.3462-3472, 2001.

SPAROVEK, G. Erosão do solo e a produtividade das culturas. In: SOIL SCIENCE LATIN-AMERICAN CONGRESS, 13., Águas de Lindóia, 1996. Abstracts. Campinas: Software Gráfico, 1996.

STRAHLER, A.N. Quantitative analysis of watershed geomorphology. Transaction of American Geophysical Union, v.38, p.913-920, 1957.

WISCHMEIER, W.H.; SMITH, D.D. Predicting rainfall erosion losses: a guide to conservation planning. Washington: USDA Science and Education, 1978. 58p.

Received September 30, 2006

Accepted April 26, 2007 